\title{
Efficiency of Rice Husk for Removal of Cu(II) and Zn(II) lons from Aqueous Solution
}

\author{
Belete Geremew $^{1}$, Tesfahun Kebede ${ }^{2}$ \\ ${ }^{1}$ Department of Chemistry, School of Natural Science, Madda Walabu University, Bale-Robe, Ethiopia \\ ${ }^{2}$ Department of Chemistry, College of Natural and Computational Science, Haramaya University, Haromaya, Ethiopia
}

\section{Email address:}

belete.tigabu@gmail.com (B. Geremew)

\section{To cite this article:}

Belete Geremew, Tesfahun Kebede. Efficiency of Rice Husk for Removal of Cu(II) and Zn(II) Ions from Aqueous Solution. Science Journal of Analytical Chemistry. Vol. 5, No. 5, 2017, pp. 66-71. doi: 10.11648/j.sjac.20170505.11

Received: June 23, 2016; Accepted: July 4, 2016; Published: October 11, 2017

\begin{abstract}
In the present study the adsorption of $\mathrm{Cu}(\mathrm{II})$ and $\mathrm{Zn}(\mathrm{II})$ ions on rice husk from artificially prepared aqueous solutions of these metal ions was investigated following the batch mode adsorption procedure. Accordingly, the effects of operating parameters such as $\mathrm{pH}$, contact time, and initial concentration of metal ion solution were evaluated. The results so obtained in this study indicated that the optimum conditions for the $\mathrm{Cu}(\mathrm{II})$ and $\mathrm{Zn}(\mathrm{II})$ ions adsorption were found to be as follows: $\mathrm{pH}$ of 6 and 7; contact times of 100 and 125 minutes; and these values were actually determined by setting the initial concentration of $50 \mathrm{mg} / \mathrm{L}$ for each metal ion solution. Upon measurements of the residual metal ion concentration using FAAS method, the percent adsorption of both $\mathrm{Cu}(\mathrm{II})$ and $\mathrm{Zn}$ (II) ions showed significant increase with an increase in each case of the contact time. Furthermore, it was evidently implicated that the binding process of the metal ions on the adsorbent (rice husk) could be affected by change in the $\mathrm{pH}$ of both metal ion solutions. In addition the experimental data were analyzed against both Langmuir and Freundlich isotherm for determining the maximum adsorption capacity of the title biosorbent with respect to each of the tested metal ions. The adsorption maxima were calculated on the basis the Langmuir isotherm and found to be 1.93 and $12.98 \mathrm{mg} / \mathrm{g}$ for $\mathrm{Cu}(\mathrm{II})$ and $\mathrm{Zn}(\mathrm{II})$ metal ions respectively. These values were suggested that the rice husk investigated in this study can have a good application potential for the removal of both metal ions $(\mathrm{Cu}(\mathrm{II})$ and $\mathrm{Zn}(\mathrm{II}))$ from aqueous solutions. In fact, the goal of this work was to develop an inexpensive, highly available, effective metal ion adsorbent from natural waste as alternative to existing commercial adsorbents.
\end{abstract}

Keywords: Adsorption Efficiency, Adsorption Isotherm, Batch Adsorption, Copper, Rice Husk, Zinc

\section{Introduction}

Heavy metals are wide spread pollutants of the environment and they are non-degradable [1]. It is well perceived that there is a permissible limit of each metal, above which it is generally toxic. Wastewaters commonly have $\mathrm{Cu}, \mathrm{Ni}, \mathrm{Cr}, \mathrm{Cd}$, and $\mathrm{Pb}$. Since all these heavy metals are not biodegradable, their presence in streams and lakes leads to bioaccumulation in living organisms, causing health problems in animals, plants, and human beings [2]. Due to their accumulation through food chain and persistence in nature, it is necessary to remove these toxic heavy metals from wastewater.

At present there is numerous methods inexistence for the removal of detrimental metal ions from aqueous solutions that can make use of either of the conventional and nonconventional technologies. Conventional technologies include: chemical precipitation, ion-exchange, membrane separation and adsorption by activated carbon. But, conventional technologies have some drawbacks like high operational cost or disposal of resulting sludge [3]. The effluent treatment in developing countries is expensive. Due to the above drawbacks of conventional technologies, nonconventional (locally available) materials are used for the removal and recovery of heavy metals from industrial wastewater [4]. For example, the adsorption of metals on different microbial and agricultural wastes like treated and untreated mushroom, barley straw, mango seed husk, coconut husk, sawdust, sugarcane bagasse and coffee husk etc. in different countries has been reported.

Copper and zinc metals are a serious cause of 
environmental pollution if their concentration is above permissibility limit. Therefore, it is necessary to alleviate those ions from industrial effluents. There are different methods for zinc and copper metals treatments have been described by physical and chemical processes. For example, precipitation, coagulation, reduction, membrane processes, ion-exchange and adsorption etc. However, those techniques have their own inherent limitation such as: less efficiency, sensitive operating conditions, and production of secondary sludge requiring further costly disposal. These disadvantages have resulted in the development of alternative separation technologies. One such alternative method is biosorption [5].

Rice husk (RH) consists of cellulose (32.24\%), hemicelluloses $(21.34 \%)$, lignin $(21.44 \%)$ and mineral ash $(15.05 \%)$ as well as high percentage of silica in its mineral ash. It is insoluble in water, has good chemical stability and mechanical strength making it a good adsorbent material for treating heavy metals from wastewater. It is used to treat heavy metals in the form of either untreated or modified form [6]. The FTIR spectra of raw rice husk show the following peaks; at $796 \mathrm{~cm}^{-1}$ due to $\mathrm{C}-\mathrm{H}$ bending vibration; at $1076 \mathrm{~cm}^{-1}$ due to $\mathrm{C}-\mathrm{O}$ stretching vibration; at $1646 \mathrm{~cm}^{-1}$ is due to $\mathrm{N}-\mathrm{H}$ stretching vibration; at $1735 \mathrm{~cm}^{-1}$ is due to $\mathrm{C}=\mathrm{O}$ stretching; at $2855 \mathrm{~cm}^{-1}$ due to $\mathrm{C}-\mathrm{H}$ stretching vibration and abroad peak at $3430 \mathrm{~cm}^{-1}$ due to $\mathrm{O}-\mathrm{H}$ stretching. The mechanism of sorption for the raw and modified forms of rice husk is linked to the role played by the essential stretching functional groups like hydroxyl $(-\mathrm{OH})$, carboxylic acid $(-\mathrm{COOH})$, carbonyl $(\mathrm{C}=\mathrm{O})$, $\mathrm{Si}-\mathrm{O}-\mathrm{Si}, \mathrm{Si}-\mathrm{OH}$, aromatic and phenolic groups existing in the sorbent. Such functional groups can be increased in concentration and/or can be created by the action of chemical modifiers [7]. The adsorption capacity of treated rice husk to remove $\mathrm{Cu}$ (II) and $\mathrm{Zn}$ (II) ions from aqueous solution was reported by researchers. But, there is a research gap on adsorption efficiency of untreated rice husk for removing $\mathrm{Cu}(\mathrm{II})$ and $\mathrm{Zn}(\mathrm{II})$ ions from aqueous solution.

\section{Materials and Methods}

\subsection{Apparatus and Instruments}

The apparatus used in this study were: $\mathrm{pH}$ meter (MP220) to measure $\mathrm{pH}$ of the solution, AAS (GBC932plus) to measure metal ion concentration, Mechanical shaker (Orbital shaker SO, UK) to agitate the sample, Electronic balance (OHAUS, Switzerland) for weighting, Desiccator (Nikko Japan super dry SD504) to keep a sample less humid, Electrical mill (IKAWERKE) to grind sample, Erlenmeyer flask, What man No. 42 filter paper, Sieve, and Hot air oven to dry sample.

\subsection{Chemicals and Reagents}

Analytical grade reagents; $\mathrm{CuSO}_{4} \cdot 5 \mathrm{H}_{2} \mathrm{O}$ (Himedia Laboratories Pvt. Ltd), $\mathrm{ZnSO}_{4} .7 \mathrm{H}_{2} \mathrm{O}$ (Laboratory reagent, India) were used to prepare standard solutions of the metals studied. Concentrated $\mathrm{HNO}_{3}$ (S.d.fi NE-CHEM Limited MUMBAI 400030), $\mathrm{NaOH}$ (IP241HPUKUN), $\mathrm{HCl}$ (Blulux
Laboratories (p) Ltd-121001), $\mathrm{NaCl}$ (UN1-CHEMS34900-3I) were also used.

\subsection{Experimental Site and Rice Husk Collection}

Rice husk was collected from Woreta Rice Processing Unit which is located in Southern Gonder, Amhara regional state of Ethiopia, 1,116 km from Haramaya University or $593 \mathrm{~km}$ North-West of Addis Ababa. The rice husk was collected from rice mill using plastic bags. The batch mode adsorption experiment was done at the Haramaya University Chemistry Department Laboratory.

\subsection{Experimental Procedure}

\subsubsection{Cleaning of Laboratory Equipment}

All the sample containers were thoroughly washed with detergent, rinsed with distilled water before soaking in $10 \%$ $\mathrm{HNO}_{3}$ for about 24 hours. Containers were finally rinsed with de-ionized water before being used.

\subsubsection{Rice Husk Collection and Preparation}

The rice husk was collected from rice mill using plastic bags. Then, the raw rice husk was cleaned by distilled water and dried at $100^{\circ} \mathrm{C}$ for $24 \mathrm{~h}$ in a hot air oven before ground by electrical mill and allowed to pass through $250 \mu \mathrm{m}$ sieve.

\subsubsection{Preparation of Adsorbate Solutions}

$1000 \mathrm{mg} / \mathrm{L}$ stock solutions of $\mathrm{Cu}$ (II) and $\mathrm{Zn}$ (II) ions were prepared by dissolving $3.93 \mathrm{~g}$ of $\mathrm{CuSO}_{4} .5 \mathrm{H}_{2} \mathrm{O}$ and $4.4 \mathrm{~g}$ of $\mathrm{ZnSO}_{4} \cdot 7 \mathrm{H}_{2} \mathrm{O}$ respectively in de-ionized water. Then, a few drops of $0.1 \mathrm{M} \mathrm{HNO}_{3}$ were added to each stock solution to prevent the precipitation of $\mathrm{Cu}$ (II) and $\mathrm{Zn}$ (II) by hydrolysis. Finally, the required working solutions were prepared by pipeting a known amount of the stock solutions into Erlenmeyer flask and diluting using the required amount of de-ionized water.

\subsubsection{Adsorption Studies}

For individual metal ions were carried out at $25 \pm 1^{\circ} \mathrm{C}$ and $20 \mathrm{~g} / \mathrm{L}$ of adsorbent dosage. The effects of different parameters such as adsorbate concentration, contact time, and $\mathrm{pH}$ were studied. The batch mode adsorption studies were carried out in $250 \mathrm{~mL}$ Erlenmeyer flask and the flask was shaken for a prescribed length of time by orbital shaker. Then, thorough filtration using filter paper was done. Finally, the amount of $\mathrm{Cu}^{2+}$ and $\mathrm{Zn}^{2+}$ ions remaining in solution in each case was determined by FAAS.

Effect of Contact Time, $\mathrm{pH}$ and Initial Concentration of Metal Ion Solution

Contact time is one of the most important parameters for the assessment of practical application of adsorption process. For the determination of the rate of metal adsorption by the rice husk from $100 \mathrm{~mL}$ of solution, the quantity of metal ion adsorbed was determined by varying the contact time as 25 , $50,75,100,125,150,175$ minutes and other parameters were kept constant. To determine the effect of $\mathrm{pH}$, the solutions $\mathrm{pH}$ was adjusted to $2,3,4,5,6,7,8$ and 9 by using $0.1 \mathrm{M} \mathrm{HCl}$ and $0.1 \mathrm{M} \mathrm{NaOH}$ solutions prior to the experiment 
and other parameters were kept constant. Finally, to determine the effect of metal ions concentration on metal removal efficiency of adsorbent, the metal ion concentration of $10,20,30,40,50 \mathrm{mg} / \mathrm{L}$ were used and other parameters were kept constant.

\subsubsection{Measurement and Calculation}

For calibration purpose, standards and blank (de-ionized water) were run in flame atomic absorption spectrometer before the analysis of the samples. Then, the concentration of each metal ion was determined from the calibration curve. All determinations were performed in a total of three replicates and the average values were reported. Finally, removal efficiency was calculated by using the following relationship;

$$
\text { Adsorption }(\%)=((\mathrm{Co}-\mathrm{Ce}) / \mathrm{Co}) \times 100
$$

Where; $\mathrm{Co}$ and $\mathrm{Ce}$ are the initial and equilibrium concentration of adsorbate respectively

The adsorption capacity of the rice husk was calculated based on the following equation;

$$
\mathrm{qe}=(\mathrm{Co}-\mathrm{Ce}) \times \mathrm{V} / \mathrm{m}
$$

Where; qe is the adsorbed metal ion on the sorbent, $\mathrm{m}$ is the weight of sorbent; $\mathrm{V}$ is the volume of metal ion solution.

\subsection{Data Analysis and Interpretation}

The data generated were analyzed by using Microsoft Office Excel 2007 to compute the mean, standard deviation and linear regression values. Finally, the adsorption efficiency of a rice husk for removal of $\mathrm{Cu}$ (II) and $\mathrm{Zn}$ (II) ions was evaluated.

\section{Results and Discussion}

\subsection{The Optimum Condition for Cu (II) and Zn (II) Ions Removal by Rice Husk}

\subsubsection{Effect of Contact Time}

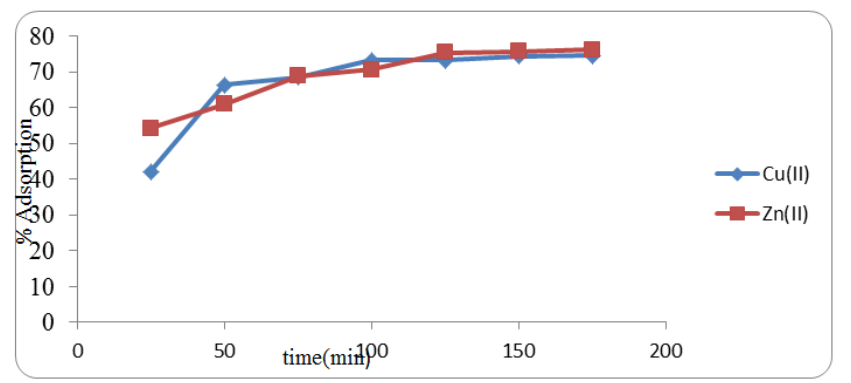

Figure 1. $\mathrm{Cu}(\mathrm{II})$ and $\mathrm{Zn}(\mathrm{II})$ ions adsorption efficiency(\%) at various contact time $(C o=50 \mathrm{mg} / \mathrm{L}$, adsorbent dosage $=20 \mathrm{~g} / \mathrm{L}$, solution $\mathrm{pH}=6$ and 7 , agitation speed $=150 \mathrm{rpm}$ and $200 \mathrm{rpm}$ respectively).

From figure 1, the percentage rates of both copper and zinc adsorption have rapidly increased at the beginning. This is may be due to larger surface area of the husk being available at beginning for the adsorption of $\mathrm{Cu}$ (II) and $\mathrm{Zn}$ (II) ions. As the surface adsorption sites become exhausted, the uptake rate is controlled by the rate at which the adsorbate is transported from the exterior to the interior sites of the adsorbent particles. With the progressive occupation of these sites, the process becomes slower. This is in accordance with the observations in other similar studies [8]. Almost $73.24 \pm 0.07 \% \mathrm{Cu}$ (II) ions were removed in first 100 minutes. In the case of $\mathrm{Zn}(\mathrm{II}), 75.44 \pm 0.030 \%$ of the ions was adsorbed in first 125 minutes. Therefore, 100 minutes for $\mathrm{Cu}(\mathrm{II})$ and 125 minutes for $\mathrm{Zn}$ (II) ions can be taken as sufficient contact times for attaining equilibrium.

\subsubsection{Effect of $\mathrm{pH}$}

The effect of solution $\mathrm{pH}$ on adsorption efficiency of $\mathrm{Cu}(\mathrm{II})$ and $\mathrm{Zn}$ (II) ions from aqueous solution is shown in Figure 2.

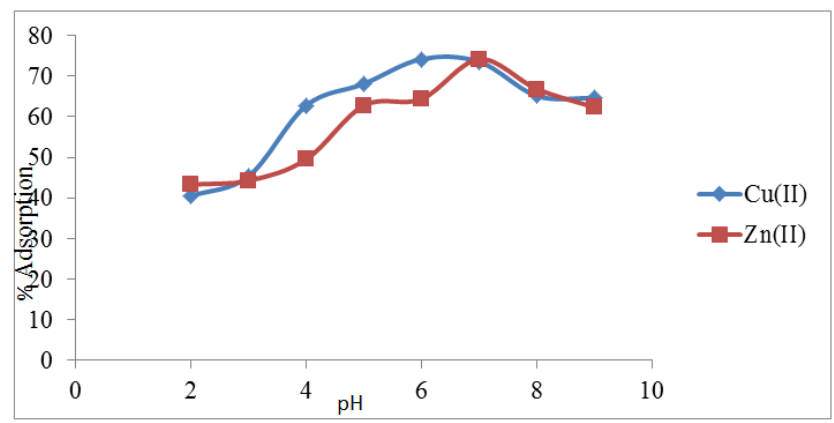

Figure 2. Effect of $\mathrm{pH}$ on $\mathrm{Cu}$ (II) and $\mathrm{Zn}$ (II) ions adsorption efficiency (\%) $(\mathrm{Co}=50 \mathrm{mg} / \mathrm{L}$, adsorbent dosage $=20 \mathrm{~g} / \mathrm{L}$, time $=100 \mathrm{~min}$ and $125 \mathrm{~min}$, agitation speed $=150 \mathrm{rpm}$ and $200 \mathrm{rpm}$ respectively).

The plots in figure 2 show that the adsorption efficiency of both $\mathrm{Cu}(\mathrm{II})$ and $\mathrm{Zn}$ (II) ions onto the surface of adsorbent increases as the $\mathrm{pH}$ of the metal ion solution increases. In both cases, adsorption is gradual increase up to $\mathrm{pH} 3$, but it becomes drastic after this $\mathrm{pH}$. The trend continues until the maximum adsorption values of $74.21 \pm 0.080 \%$ (at $\mathrm{pH} 6$ ) and $74.17 \pm 0.075 \%$ (at $\mathrm{pH} 7$ ) were attained for $\mathrm{Cu}(\mathrm{II})$ and $\mathrm{Zn}(\mathrm{II})$ ions respectively. These values were taken to be the optimum amounts of metal ions that could be removed from the respective solution via adsorption on the rice husk surface.

$\mathrm{pH}$ (below 3), there was excessive protonation of the active sites of the rice husk surface that might have prohibited the formation of links between the $\mathrm{Cu}(\mathrm{II})$ and $\mathrm{Zn}$ (II) ions and the active sites. At moderate $\mathrm{pH}$ values of 3 to 6 for copper and 3 to 7 for zinc, most of the linked $\mathrm{H}^{+}$ions were supposed to be released from the active sites and this resulted in an increase in the amount of metal ions adsorbed. The peak percentage adsorptions of $\mathrm{Cu}(\mathrm{II})$ and $\mathrm{Zn}$ (II) were attained at $\mathrm{pH} 6$ and 7 respectively. After optimum $\mathrm{pH}$, the observed decrease in adsorption of $\mathrm{Cu}$ (II) ions may be due to formation of $\mathrm{Cu}(\mathrm{OH})_{2}$ precipitate. At higher $\mathrm{pH}$ values (7 to 9) the $\mathrm{OH}^{-}$ions may compete for $\mathrm{Zn}(\mathrm{II})$ ions with the active sites on the surface of the adsorbents causing a decrease in the adsorption rate might be due to formation of $\mathrm{Zn}(\mathrm{OH})_{2}$ precipitate. Similar results were obtained by using rice husk ash by many researchers.

Evidences show that the $\mathrm{pH}$ of solution affects the 
solubility of metal ions and concentration of the counter ions on the functional groups of the biomass cell walls. This is partly due to the fact that hydrogen ions $\left(\mathrm{H}^{+}\right)$themselves are strong competing ions and partly that the solution $\mathrm{pH}$ influences the chemical speciation of the functional groups onto the adsorbent surfaces. At low $\mathrm{pH}$, due to high positive charge density and protons on the surface sites during uptake of metal ions, electrostatic repulsion will be high resulting in lower removal efficiency as electrostatic repulsion decreases with increasing $\mathrm{pH}$. Thus enhancement of metal ion adsorption is noted [9].

\subsubsection{Effect of Initial Concentration of Metal Ion}

The effect of initial concentration of adsorbate on the rate of adsorption was investigated by varying the initial concentration of each of $\mathrm{Cu}$ (II) and $\mathrm{Zn}$ (II) ions between 10 and $50 \mathrm{mg} / \mathrm{L}$. The results obtained in this regard are shown in figure 3.

From figures 3, an increase in the initial concentration of each of $\mathrm{Cu}$ (II) and $\mathrm{Zn}$ (II) ions leads to an increase in the adsorption capacity of the ions by $\mathrm{RH}$. However, the percentage adsorption of copper and zinc ions on the adsorbent decreased from $98.79 \pm 0.010 \%$ at $10 \mathrm{mg} / \mathrm{L}$ to $74.24 \pm 0.055 \%$ at $50 \mathrm{mg} / \mathrm{L}$ for $\mathrm{Cu}$ (II) ions and $74.20 \pm 0.10 \%$ at $10 \mathrm{mg} / \mathrm{L}$ to $72.13 \pm 0.011 \%$ at $50 \mathrm{mg} / \mathrm{L}$ for $\mathrm{Zn}$ (II) ions. This is in agreement with the results of heavy metals removal by low-cost adsorbents [10]. In case of low concentrations of metal ions the ratio of the initial number of moles of each of $\mathrm{Cu}(\mathrm{II})$ and $\mathrm{Zn}(\mathrm{II})$ ions to the available surface area is large. In consequence, all $\mathrm{Cu}$ (II) and $\mathrm{Zn}$ (II) ions present in the solution could have interacted with the binding sites and thus the percentage adsorption became higher than those observed at higher initial copper and zinc ion concentrations.

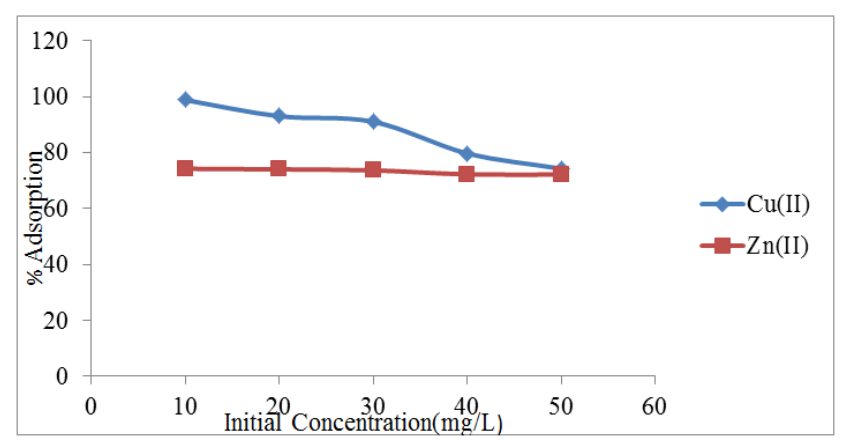

Figure 3. Effect of initial concentration on $\mathrm{Cu}(\mathrm{II})$ and $\mathrm{Zn}$ (II) ions adsorption efficiency (\%) (Adsorbent dosage $=20 \mathrm{~g} / \mathrm{L}$, time $=100 \mathrm{~min}$ and $125 \mathrm{~min}$, solution $\mathrm{pH}=6$ and, agitation speed $=150 \mathrm{rpm}$ and $200 \mathrm{rpm}$ respectively).

\subsection{Adsorption Isotherms}

The present experiment used the Langmuir and Freundlich equations to explain the nature of adsorption of the two metal $(\mathrm{Cu}(\mathrm{II})$ and $\mathrm{Zn}(\mathrm{II}))$ ions. The graph plotted using the Langmuir equation can show the relationship between Ce (in the $\mathrm{X}$-axis) and Ce/qe (in the $\mathrm{Y}$-axis), while, the graph drawn based on the Fruendlich equation shows the relationship between $\log \mathrm{Ce}$ (in the $\mathrm{X}$-axis) and logqe (in the $\mathrm{Y}$-axis).

\subsubsection{Copper Adsorption Isotherm}

Table 1. The results of $\mathrm{Cu}(\mathrm{II})$ ions adsorption isotherm.

\begin{tabular}{|c|c|c|c|c|c|}
\hline Initial concentration $\mathrm{Co}(\mathrm{mg} / \mathrm{L})$ & Final concentration $\mathrm{Ce}(\mathrm{mg} / \mathrm{L})$ & Adsorption capacity(qe)(mg/g) & $\mathrm{Ce} / q \mathrm{qe}$ & $\log C e$ & Logqe \\
\hline 10 & 0.12 & 0.49 & 0.24 & -0.92 & -0.30 \\
\hline 20 & 1.40 & 0.93 & 1.50 & 0.14 & -0.03 \\
\hline 30 & 2.70 & 1.36 & 1.98 & 0.43 & 0.13 \\
\hline 40 & 8.11 & 1.59 & 5.10 & 0.90 & 0.20 \\
\hline 50 & 12.88 & 1.85 & 6.96 & 1.10 & 0.26 \\
\hline
\end{tabular}

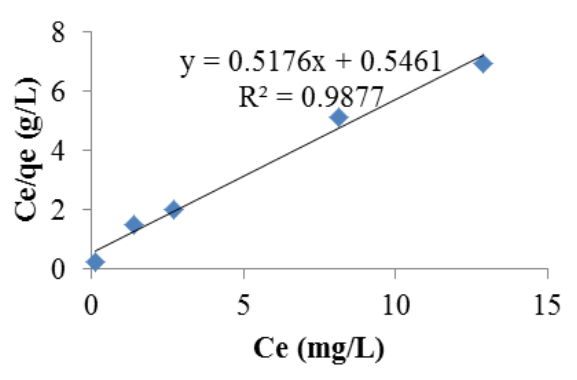

Figure 4. Langmuir adsorption isotherms for Cu(II)ions.

The essential characteristics of Langmuir isotherms can be expressed in terms of dimensionless equilibrium parameter $\mathrm{K}_{\mathrm{L}}[11]$.

$$
\mathrm{K}_{\mathrm{L}}=1 /(1+\mathrm{KaCo})
$$

Where; Co is initial metal ion concentration in solution
(mg/L), $\mathrm{Ka}$ is Langmuir constant related to adsorption energy.

From Figure 4 and equation 3, the empirical constants qm and $\mathrm{Ka}$ were found to be $1.93 \mathrm{mg} / \mathrm{g}$ and 0.94 , respectively. The value of qm show, one gram of the rice husk can adsorb $1.93 \mathrm{mg}$ copper. The value of $\mathrm{KL}$ indicates a favorable adsorption $(0<1 /(1+0.94 \mathrm{Co})<1)$. This means that $\mathrm{RH}$ is a favorable adsorbent for the removal of $\mathrm{Cu}$ (II) ions from aqueous solutions.

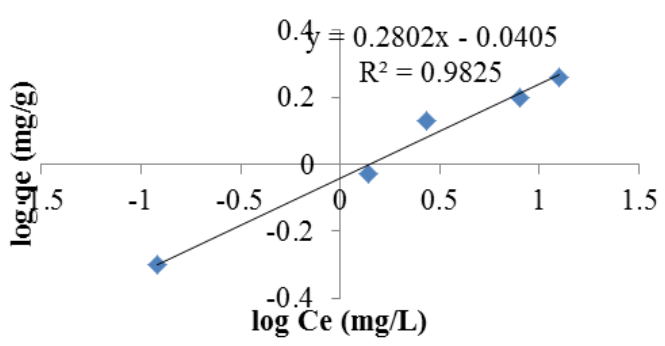

Figure 5. Freundlich adsorption isotherm for Cu(II) ions. 
According to [12] the Freundlich equation is expressed as:

$$
\mathrm{qe}=\mathrm{K}_{\mathrm{F}} \mathrm{Ce}^{1 / \mathrm{n}}
$$

Where; $\mathrm{K}_{\mathrm{F}}$ and $\mathrm{n}$ are adsorption capacity and intensity respectively

The linear form Freundlich isotherm is given by the following equation;

$$
\text { Logqe }=\log \mathrm{K}_{\mathrm{F}}+1 / \mathrm{nlog} \mathrm{Ce}
$$

By using Figure 5 and equation 4 , the Freundlich constants $K_{F}$ and $\mathrm{n}$ were found to be 0.912 and 3.57 , respectively. The value of $1 / n$ shows the concentration of solute adsorption. If the value of $1 / \mathrm{n}$ is close to 1 , it shows that just a little concentration change can relatively affect the adsorption. If $\mathrm{n}$ is more than 1 , it means the adsorbent can effectively adsorb the solute [12]. Since the values of $1 / \mathrm{n}(0.280)$ lie between 0 and 1 and $n>1$, it indicates that the $\mathrm{RH}$ can adsorb $\mathrm{Cu}$ (II) ions effectively. The copper adsorption on $\mathrm{RH}$ fitted to both Langmuir and Freundlich adsorption isotherms since the correlation coefficients $\left(\mathrm{R}^{2}\right)$ are 0.987 and 0.982 respectively. Therefore, each site of a RH can accommodate one copper ion or it is characterized by heterogeneity of surfaces of $\mathrm{RH}$.

\subsubsection{Zinc Adsorption Isotherms}

\begin{tabular}{|c|c|c|c|c|c|}
\hline Initial concentration $\mathrm{Co}(\mathrm{mg} / \mathrm{L})$ & Final concentration $\mathrm{Ce}(\mathrm{mg} / \mathrm{L})$ & Adsorption capacity(qe)(mg/g) & $\mathrm{Ce} / q \mathrm{q}$ & $\operatorname{LogCe}$ & Logqe \\
\hline 10 & 2.58 & 0.37 & 6.97 & 0.41 & -0.43 \\
\hline 20 & 5.20 & 0.74 & 7.02 & 0.71 & -0.13 \\
\hline 30 & 7.90 & 1.10 & 7.18 & 0.89 & 0.04 \\
\hline 40 & 11.10 & 1.44 & 7.70 & 1.04 & 0.15 \\
\hline 50 & 13.93 & 1.80 & 7.73 & 1.14 & 0.25 \\
\hline
\end{tabular}

Table 2. The results of Zn(II) ions adsorption isotherm.

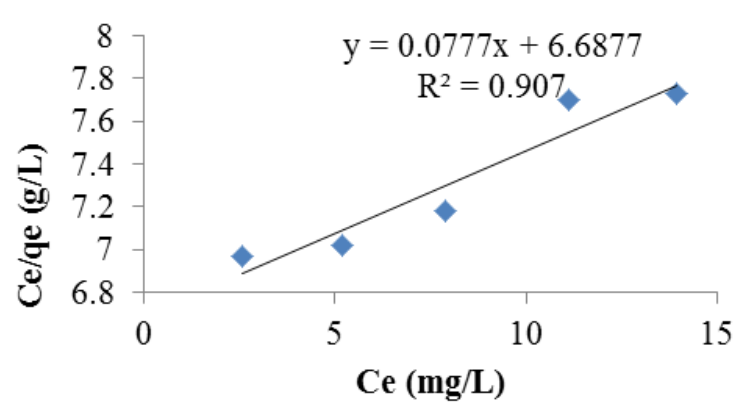

Figure 6. Langmuir adsorption isotherm for Zn(II) ions.

From Figure 6 and equation 3, the empirical constants qm and $\mathrm{Ka}$ were found to be $12.98 \mathrm{mg} / \mathrm{g}$ and 0.011 , respectively. Also, the value of KL indicates a favorable adsorption $(0<$ $\mathrm{KL}<1)$. This means that $\mathrm{RH}$ is a favorable adsorbent for the removal of $\mathrm{Zn}(\mathrm{II})$ ions from aqueous solutions. Therefore, the adsorption of $\mathrm{Zn}(\mathrm{II})$ ions on $\mathrm{RH}$ is feasible.

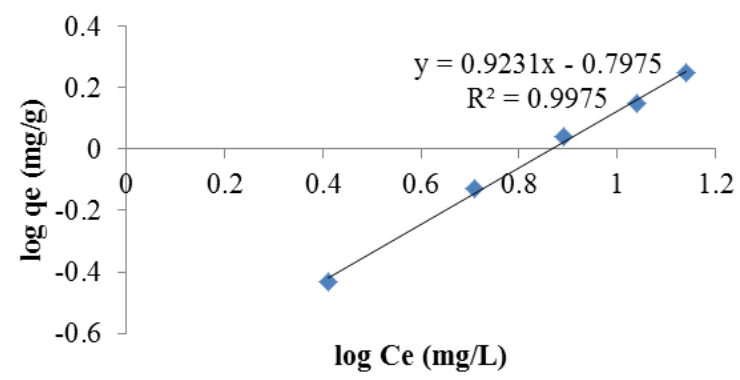

Figure 7. Freundlich adsorption isotherm for Zn(II)ions.

From Figure 7 and equation 4 , the Freundlich constants $\mathrm{K}_{\mathrm{F}}$ and $\mathrm{n}$ were found to be 0.159 and 1.083 , respectively. Since the values of $1 / \mathrm{n}(0.923)$ lie between 0 and 1 and $n>1$, it indicates that the RH can also adsorb $\mathrm{Zn}$ (II) ions effectively. The adsorption of $\mathrm{Zn}(\mathrm{II})$ ions on $\mathrm{RH}$ better fitted to the Freundlich model than to the Langmuir model as the correlation coefficients $\left(\mathrm{R}^{2}\right)$ are found to be 0.997 and 0.907 respectively.

\section{Conclusions}

It is obvious that many industries are releasing their effluents directly to the water bodies without pretreatment, it might be due lack of efficient or economically feasible means. Adsorption is a strong choice for removal of heavy metals from the wastewater. A simple and cost effective treatment procedure was proposed for the removal of heavy metals through the adsorption on rice husk. Removal of copper and zinc ions by rice husk has been shown to depend significantly on the $\mathrm{pH}$, initial metal ion concentration, and contact time. Rice husk efficient effective adsorbent for removal of $\mathrm{Cu}(\mathrm{II})$ and $\mathrm{Zn}(\mathrm{II})$ ions from aqueous solution.

\section{References}

[1] Stratton, G. W., 1987. Review in Environmental Toxicology. Elsevier, Amsterdam. 56: 85-94

[2] Mehmet, E., D. Sukru, O. Celalettin and K. Mustafa, 2007. Heavy metal adsorption by modified oak sawdust: Thermodynamic sand kinetics. J. Hazardous Materials, 141(1): 77-85

[3] Gabaldon, C., P. Marzaland, A. Seco, 1996. Cadmium and zinc adsorption onto activated carbon: influence of temperature, $\mathrm{pH}$ and metal/carbon ratio. J. Chem. Technol. Biotechnol. 66: 279-285

[4] Ahalya, N., T. Ramachandra and D. Kanamadi, 2005. Biosorption of chromium(VI) from aqueous solutions by the husk of bengalgram (Cicerarientinum). Electronic $J$. Biotechnology, 99: 13-15

[5] Norton, K., 2004. Biosorption of zinc from aqueous solutions using biosolids. Adv. Environ. Res. 8: 629-635 
[6] Esteghlalian, A., A. Hashimoto, J. Fenske and M. Penner, 1997. Modeling and optimization of the dilute-sulfuric-acid pretreatment of corns over, poplar and switch grass. Bioresour. Technol. 5: 129-136

[7] Gordon, E., J. Brown and D. John, 1999. Mineral surfaces and bioavailability of heavy metals: A molecular-scale perspective. J. proc Natl Acad. Sci. USA. 96(7): 3388-3395

[8] Nadeem, F., N. Ramzan, A. Khan and I. Iqbal, 2010. Kinetic and equilibrium studies for $\mathrm{Zn}(\mathrm{II})$ and $\mathrm{Cu}(\mathrm{II})$ metal ions removal using biomass ash. J. Chem. Soc. Pak. 33(2): 139

[9] Taty-Costodes, V. C., H. Fauduet, C. Porte and A. Delacroixs,
2003. Removal of $\mathrm{Cd}(\mathrm{II})$ and $\mathrm{Pb}(\mathrm{II})$ ions from aqueous solutions by adsorption onto sawdust of Pinus Sylvestris. $J$. Hazardous Materials, 105(1-3): 121-142

[10] Ragheb, S. M., 2007. Recovery of heavy metals from wastewater using low-cost adsorbents. Cairo University. $J$. Adv. 2(4): 297-303

[11] Langmuir, I., 1918. The constitution and fundamental properties of solids and liquids. J. Am. Chem. Soc. 38: 22212295

[12] Freundlich, H., 1906. Ueberdie Adsorption in Loesungen. $Z$. phys. Chem. 57: 385-470 